\title{
NODULE SENESCENCE AND BIOMASS COMPONENTS IN COMMON BEAN CULTIVARS
}

\section{SENESCENCIA NODULAR Y COMPONENTES DE BIOMASA EN CULTIVARES DE FRIJOL COMÚN}

\author{
Fabián Fernández Luqueño ${ }^{1}$, David Espinosa Victoria ${ }^{2 *}$, Antonio Munive ${ }^{3}$, Langen Corlay Chee ${ }^{4}$ y \\ Luis M. Serrano Covarrubias ${ }^{5}$
}

\footnotetext{
${ }^{1}$ Departamento de Biotecnología y Bioingeniería, Centro de Investigación y de Estudios Avanzados, Instituto Politécnico Nacional. Av. IPN No. 2508, México, D. F. ${ }^{2}$ Instituto de Recursos Naturales, Colegio de Postgraduados. 56230, Montecillo, Texcoco, México. Tel. 01 (595) $952-0200$ Ext. 1273. ${ }^{3}$ Instituto de Ciencias, Benemérita Universidad Autónoma de Puebla. Puebla, México. ${ }^{4}$ Departamento de Suelos y ${ }^{5}$ Departamento de Fitotecnia, Universidad Autónoma Chapingo. 56230, Chapingo, México.
}

*Autor para correspondencia (despinos@colpos.mx)

\section{SUMMARY}

Most legumes establish mutualistic symbiotic relationships with atmospheric nitrogen-fixing bacteria (rhizobia), giving origin to nodules. Nodules exhibit natural or induced aging which coincides with the drop in nitrogenase activity at the flowering period or at the pod filling stage. In this research, the onset of nodule senescence (NS) was evaluated under greenhouse conditions in five common bean (Phaseolus vulgaris L.) cultivars of two growth habits, determined (Type I) and indeterminate (Type III), inoculated with Rhizobium etli CE-3. Weekly destructive samplings were taken to determine nitrogen fixation by the acetylene reduction assay, the number and fresh weight of nodules, as well as root and above ground biomass dry weight. It was found that NS in bean appears to be independent of host plant phenological stage (flowering or pod filling), the longer period the symbiotic system is fixing nitrogen the greater yield is obtained, and that the nodules number and fresh weight are reliable indicators of the nitrogen fixation capacity. aging.

Index words: Phaseolus vulgaris, nitrogen fixation, rhizobia, nodule

\section{RESUMEN}

La mayoría de leguminosas establecen relaciones simbióticas mutualistas con bacterias fijadoras de nitrógeno atmosférico (rizobia) y dan origen a nódulos. Los nódulos sufren envejecimiento de forma natural $o$ inducida que coincide con la disminución de la actividad nitrogenasa al inicio de la floración, o con el llenado de la vaina. En esta investigación se evaluó en invernadero el establecimiento de la senescencia nodular en cinco cultivares de frijol común (Phaseolus vulgaris $\mathbf{L}$.) con hábito de crecimiento arbustivo determinado (Tipo I) e indeterminado (Tipo III), inoculados con Rhizobium etli CE-3. Se hicieron muestreos destructivos semanales para determinar la actividad reductora de acetileno, el número y peso fresco de nódulos, así como el peso seco de raíz y de la parte aérea de la planta. Se encontró que el proceso de senescencia nodular en el cultivo de frijol ocurre independientemente de la etapa fenológica (floración o llenado de la vaina) de la planta hospedera, que los sistemas simbióticos que permanecieron fijando nitrógeno durante más tiempo obtuvieron el mayor rendimiento, y que el número y peso fresco de los nódulos son indicadores confiables del nitrógeno fijado.
Palabras clave: Phaseolus vulgaris, fijación de nitrógeno, rizobia, envejecimiento nodular.

\section{INTRODUCTION}

The common bean (Phaseolus vulgaris L.) is a legume which formed part of the four crops [maize (Zea mays L.), bean (Phaseolus spp.), squash (Cucurbita maxima Duchesne) and chile (Capsicum annum L.)] that comprised the food base for the Mesoamerican people for almost 8000 years (Barreiro, 1997). Nowadays, vast extensions of America, Asia and Africa are cultivated with common bean (Broughton et al., 2003).

An important characteristic of the common bean relies in its capacity for establishing mutualistic symbiotic relationships with bacteria, collectively denominated rhizobia (Doyle, 1994). Under limited nitrogen conditions (Schultze and Kondorosi, 1998) and through an exchange of molecular signals (Limpens and Bisseling, 2003), the nodule formation is induced (González and Marketon, 2003), being this organ the place where the atmospheric nitrogen $(\mathrm{N}=\mathrm{N})$ is reduced to ammonia [( $\left.\mathrm{NH}_{3}\right)$ (Nosengo, 2003)].

The biological nitrogen fixation (BNF) has important agronomical and environmental implications, thus a great interest in learning, understanding and predicting the entire BNF process has been generated (Martínez-Romero, 2003). Diverse studies have been conducted to quantify BNF using several methodologies. Among these, the acetylene reduction assay (ARA) is a simple, fast and inexpensive method to evaluate nitrogenase activity, as an indirect measurement of BNF (Hardarson and Danso, 1993). 
However, the nodule natural aging process, known as nodule senescence (NS), has been scarcely documented. Alesandrini et al. (2003) described NS as a rapid decline in the BNF affecting grain yield (Lawn and Brun, 1974). Pfeiffer et al. (1983) defined NS as the period in which the activity of the residual nitrogenase is lost. For Andreeva et al. (1998) and Evans et al. (1999), NS is a biochemical and physiological event that requires transcription of new genes (Howard et al., 2003) starting at the final stage of maturation and concluding with nodule death.

It has been reported that NS could be a delayed reaction of the host plant against rhizobia establishment (Staehelin et al., 1992; Puppo et al., 2005). Regarding the onset of NS, some authors indicate that it coincides with root senescence (Fisher et al., 2002), or with the senescence of the whole plant (Timmers et al., 2000). Only in some species and under certain stressing environmental conditions (Vikman and Vessey, 1992), NS occurs naturally at the start of anthesis (Andreeva et al., 1998), due to the synthesis of signals generated in the shoot (Puppo et al., 2005) or during pod filling (Vikman and Vessey, 1993a; Andreeva et al., 1998). Particularly legume root-nodules are characterized by an early senescence, compared with the senescence of any other plant organ (Evans et al., 1999). Nodule population in the root system is heterogeneous in terms of age, being the oldest, in the case of soybean [Glycine $\max$ (L.) Merrill], those formed in the main root (Espinosa-Victoria et al., 2000; McDermott and Graham, 1989). NS in legumes have been induced and studied under different adverse environmental conditions (stress), such as defoliation (Matamoros et al., 1999; Muller et al., 2001), light suppression (Swaraj et al., 1994; Gogorcena et al., 1997), excess of nitrates (Matamoros et al., 1999; Voisin et al., 2002a, b), high concentrations of $\mathrm{NaCl}$ (Comba et al., 1998; Trinchant et al., 2004), excess of contaminants such as cadmium (Balestrasse et al., 2004) and water deficit and flooding (Gogorcena et al., 1995).

The objective of the present study was to determine the NS onset in five cultivars of common bean with economic importance throughout Central México, measuring the decrease in nitrogenase activity as indicator, as well as its relationship with biomass components and with the nodules number and fresh weight.

\section{MATERIALS AND METHODS}

Five common bean cultivars with economic importance throughout Central México were evaluated. Three of them have determined growth habit (type I): 'Bayomex', 'Cacahuate 72' and 'Canario 107', and two indeterminate growth habit (type III): 'Negro Chapingo' and 'Negro Ja- mapa', all of them provided by the Departamento de Fitotecnia at the Universidad Autónoma Chapingo.

The Rhizobium etli strain CE-3, a native strain from México and frequently used as inoculums in agricultural fields (Martínez-Romero, 2003), was obtained from the Centro de Ciencias Genómicas at the Universidad Nacional Autónoma de México, Cuernavaca, Morelos, México.

Black bags $(36 \times 29 \mathrm{~cm})$ used in tree nursery in a number of 165 were filled with $4500 \mathrm{~cm}^{3}$ of fine grained red tezontle of approximately $6 \mathrm{~mm}$ in diameter. For each cultivar 33 bags were planted with four seeds uniformly distributed at $3 \mathrm{~cm}$ depth. Each bag was considered as an experimental unit, and were thinned to one seedling one week after sowing (WAS).

The bacterial strain was maintained in a yeast extractmannitol (YEM) culture medium (Graham, 1963) until used. The inoculation was carried out one WAS. One milliliter of bacterial suspension (approximately $10^{5}$ rhizobia $\mathrm{mL}^{-1}$ ) was added at the base of the stem of each seedling.

The substrate was maintained at field capacity with the following nutrient solution: $\mathrm{Ca}\left(\mathrm{NO}_{3}\right) 2_{2} 4 \mathrm{H}_{2} \mathrm{O}(2.30 \mathrm{~g})$, $\mathrm{MgSO}_{4} \cdot 7 \mathrm{H}_{2} \mathrm{O}(16.36 \mathrm{~g}), \mathrm{CaSO}_{4} \cdot 2 \mathrm{H}_{2} \mathrm{O}(14.25 \mathrm{~g}), \mathrm{K}_{2} \mathrm{SO}_{4}$ $(18.00 \mathrm{~g}), \mathrm{NaFeEDTA}(0.65 \mathrm{~g}), \mathrm{Ca}\left(\mathrm{H}_{2} \mathrm{PO}_{4}\right)_{2} 2 \mathrm{H}_{2} \mathrm{O}(3.18$ g) dissolved in $50 \mathrm{~L}$ of distilled water and adjusted to $\mathrm{pH}$ 5.8. For micronutrients, a stock solution was prepared by dissolving in $1990 \mathrm{~mL}$ of distilled water KCI $(27.9 \mathrm{~g})$, $\mathrm{H}_{3} \mathrm{BO}_{3}(25.0 \mathrm{~g}), \mathrm{MnSO}_{4}{ }^{\circ} \mathrm{H}_{2} \mathrm{O}(12.5 \mathrm{~g}), \mathrm{ZnSO}_{4} \cdot 7 \mathrm{H}_{2} \mathrm{O}(2.7$ $\mathrm{g}),\left(\mathrm{NH}_{4}\right)_{6} \mathrm{Mo}_{2} \mathrm{O}_{24} \cdot 4 \mathrm{H}_{2} \mathrm{O}(5.5 \mathrm{~g}), \mathrm{CuSO}_{4} \cdot 5 \mathrm{H}_{2} \mathrm{O}(2.5 \mathrm{~g})$ and $\mathrm{H}_{2} \mathrm{SO}_{4}(10.8 \mathrm{~mL})$. An aliquot of $10 \mathrm{Ml}$ per $50 \mathrm{~L}$ of nutrient solution was used (Fernández-Luqueño et al., 2008). Watering with nutrient solution and distilled water were alternated on a weekly basis.

\section{Acetylene reduction assay (ARA)}

ARA was done according to Roger (1982). At every sampling date, the root system of each plant was cleaned and placed in a $1.1 \mathrm{~L}$ plastic jar. Immediately, $10 \%$ of the gaseous phase in each jar was replaced with acetylene (industrial grade). The root system was exposed to acetylene for a $2 \mathrm{~h}$ period at room temperature; after this period, samples of $9 \mathrm{~cm}^{3}$ of gaseous phase from each jar were taken and kept in non additive vacutainer tubes (BD Vacutainer Cat. 366347). The amount of ethylene produced was determined with a Varian Star 3400 CX gas chromatograph (CA, USA) equipped with a flame ionization detector (FID) and a column Chrompack ${ }^{\circledR} \mathrm{Q}$ type paraplot $(365.8 \times 0.32 \times 0.22 \mathrm{~cm})$ with he as the carrier gas flowing at $25 \mathrm{~mL} \mathrm{~min}$. Injection, detection and column-oven temperatures were set at $100{ }^{\circ} \mathrm{C}, 310{ }^{\circ} \mathrm{C}$, and $32{ }^{\circ} \mathrm{C}$, 
respectively. An aliquot of $500 \mu \mathrm{L}$ per sample was injected into the chromatograph with a Teflon seal glass syringe (Hamilton ${ }^{\circledR}$, USA).

\section{Plant biomass and nodules}

The number and fresh weight (FW) of nodules, as well as the root and above ground biomass dry weight (DW) were determined by dehydration at $70{ }^{\circ} \mathrm{C}$ for $72 \mathrm{~h}$. The days from the time when plants were seeded until anthesis and pod filling were recorded.

When plants reached commercial maturity, the FW and DW of stems, roots and leaves were determined, after these parts were dried at $70{ }^{\circ} \mathrm{C}$ by $72 \mathrm{~h}$. In addition, DW of pods (without seeds) and DW of seeds per plant were registered. The pods, along with their seeds were dried at room temperature.

\section{Experimental design and statistical analysis}

The cultivars 'Bayomex', 'Cacahuate 72', 'Canario 107', 'Negro Chapingo' and 'Negro Jamapa' were inoculated with Rhizobium etli CE-3. Thirty three replicates were established per treatment. A completely randomized block design was used, with sampling date as the blocking criterion.

Each week ten destructive samplings were done analyzing 15 experimental units. The first sampling (block number one) was carried out one week after bacterial inoculation. An additional block (number eleven), was maintained until the plants reached commercial maturity.
Data were submitted to analyses of variance (ANOVA) and means separation with the Tukey test $(\mathrm{P} \leq 0.05)$, using the software Statistical Analysis System (SAS $\left.{ }^{\circledR}\right)$ version 8.0 for Windows (SAS Institute, 1989).

\section{RESULTS AND DISCUSSION}

The maximum acetylene reduction (MAR) coincided with the period after inoculation (WAI) in which flowering began in cultivar 'Negro Chapingo' (Table 1, Figure 1). Similar results were found by Pladys and Rigaud (1988) in nodules of common bean, and by Andreeva et al. (1998) in broad bean (Vicia faba L.) nodules. Also, MAR coincided with the week in which pod fill began in cultivars 'Canario 107' and 'Negro Jamapa'. Vickman and Vessey (1993a), Andreeva et al. (1998) and Salon et al. (2001) reported similar data in bean, broad bean and pea (Pisum sativum L.), respectively. Cultivars 'Bayomex', 'Cacahuate' 72, 'Canario 107' and 'Negro Jamapa' maintained the nitrogen fixation activity after flowering (Table 1), even though a strong decrease in carbohydrate rich compounds during this period has been reported (Vickman and Vessey, 1993b). In cultivars 'Bayomex' and 'Cacahuate 72', MAR occurred one and three weeks after pod fill, respectively (Table 1, Figure 1), a stage that coincides with the onset of plant senescence, as reported by Timmers et al. (2000). The above results reveal that the onset of NS varies among cultivars and is not related to the phenological stage (flowering o pod filling) of the host plant; similar data were reported by Espinosa-Victoria et al. (2000) in soybean. Furthermore, the onset of NS can vary with respect to the bacterial strain used as inoculum (Swaraj and Bishnoi, 1996; Espinosa-Victoria et al., 2000).

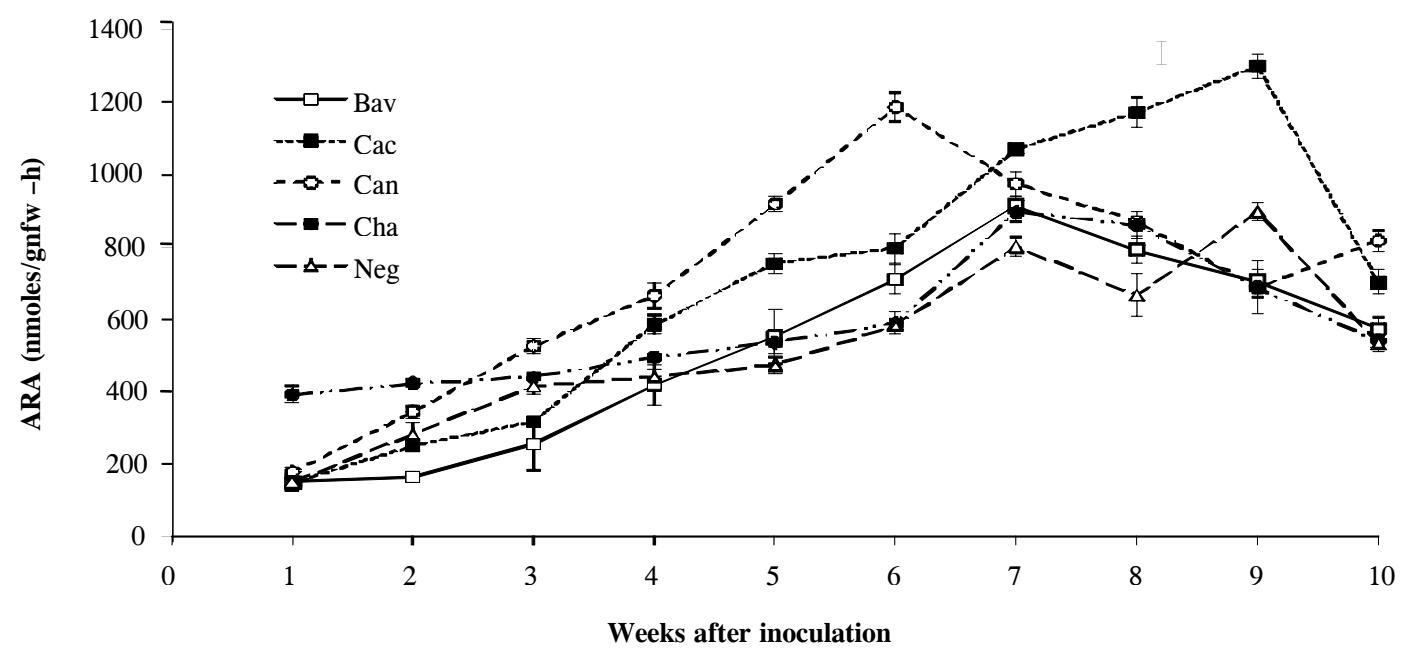

Figure 1. Acetylene reduction assay (ARA) of five common bean (Phaseolus vulgaris L.) cultivars inoculated with Rhizobium etli CE-3, measured during the lifespan of the symbiosis. Bay = 'Bayomex', Cac $=$ 'Cacahuate 72', Can = 'Carario 107', Cha $=$ 'Negro Chapingo' y Neg $=$ 'Negro Jamapa'. gnfw = grams of nodule fresh weight. Bars represent the standard error of the estimates $(P<0.05)(n=3)$. 

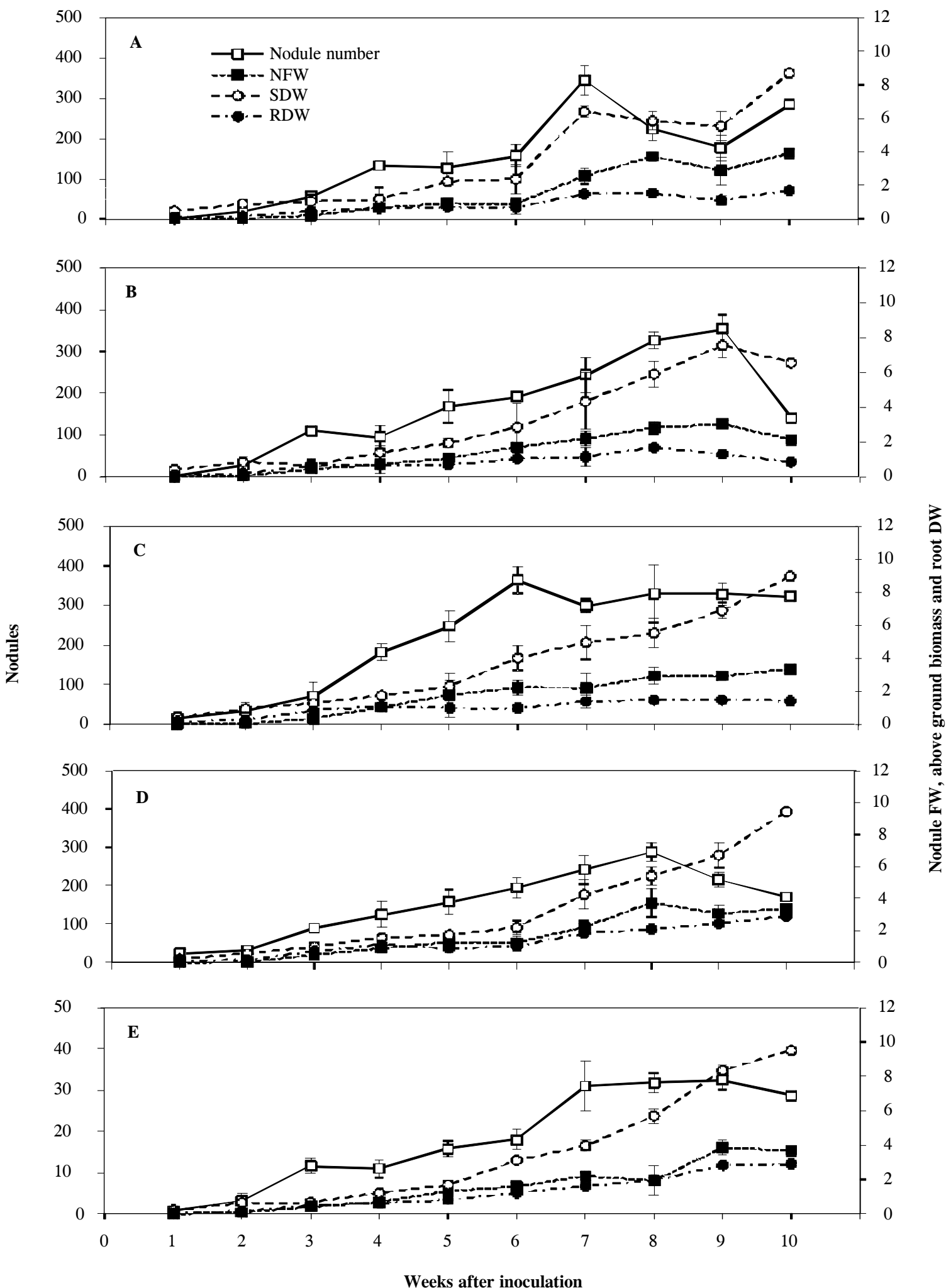

Figure 2. Number of nodules, nodule fresh weight (NFW), above ground biomass dry weight (SDW) and root dry weight (RDW) of five common bean (Phaseolus vulgaris L.) cultivars inoculated with $R$. etli CE-3, measured during the lifespan of the symbiosis. Bean cultivars: 'Bayomex' (A), 'Cacahuate 72' (B), 'Canario 107' (C), 'Negro Chapingo' (D) y 'Negro Jamapa' (E). Bars represent the standard error of the estimates (P < 0.05) $(\mathbf{n}=3)$. 
Table 1. Growth habit, weeks after inoculation when occurred the maximum acetylene reduction, flowering and pod filling in five cultivars of the Phaseolus vulgaris L.-Rhizobium etli CE-3 symbiosis.

\begin{tabular}{|c|c|c|c|c|}
\hline \multirow[b]{2}{*}{ Cultivar } & \multirow[b]{2}{*}{$\begin{array}{c}\text { Growth } \\
\text { habit }\end{array}$} & \multirow{2}{*}{$\begin{array}{l}\text { Maximum } \\
\text { acetylene } \\
\text { reduction }\end{array}$} & \multicolumn{2}{|c|}{ Growth stage } \\
\hline & & & Flowering & $\begin{array}{c}\text { Pod } \\
\text { filling }\end{array}$ \\
\hline & & \multicolumn{3}{|c|}{-------- Weeks after inoculation --------- } \\
\hline 'Bayomex' & $I^{\dagger}$ & $7 \pm 0.3 \mathrm{~b}^{\dagger \dagger}$ & $4 \pm 0.2 b$ & $6 \pm 0.2 \mathrm{~b}$ \\
\hline 'Cacahuate 72' & I & $9 \pm 0.4 \mathrm{a}$ & $4 \pm 0.3 b$ & $6 \pm 0.2 b$ \\
\hline 'Canario 107' & I & $6 \pm 0.3 \mathrm{c}$ & $4 \pm 0.3 b$ & $6 \pm 0.3 b$ \\
\hline 'Negro & III & $7 \pm 0.4 b$ & $7 \pm 0.5 \mathrm{a}$ & $9 \pm 0.4 \mathrm{a}$ \\
\hline Chapingo' & & & & \\
\hline 'Negro Jamapa' & III & $9 \pm 0.5 \mathrm{a}$ & $7 \pm 0.5 \mathrm{a}$ & $9 \pm 0.4 \mathrm{a}$ \\
\hline
\end{tabular}

With the exception of cv. 'Negro Chapingo' (Type III), the number of nodules decreased once MAR occurred (Figures 1,2) due to the fact that aged nodules were naturally detaching from the weak root tissue. Similar data were reported by Andreeva et al. (1998) in white lupinus (Lupinus albus L.) cv. 'Start', where they observed that the percentage of dead nodules increased in the phases of pod growth and seed filling. According to Hardarson and Danso (1993), Vikman and Vessey (1993a), Swaraj et al. (1995), after the week in which MAR occurred the nodules changed in color and consistency.

Cultivar 'Canario 107' exhibited the highest above ground biomass DW (Figure 2) and the lowest stem and leaf DW; however, this did not influence the seed yield (Table 2). Furthermore, 'Canario 107' fixed nitrogen during a short period time, showing the MAR at 6 weeks after sowing (Figure 1 and Table 1). On the other hand, cvs. 'Cacahuate 72' and 'Negro Jamapa' continued fixing nitrogen five and two weeks after flowering, respectively, reaching their MAR at nine weeks after inoculation (Figure 1) and obtained the highest seed yield (Table 2). This suggests that the larger the time the plant takes to reach MAR, the seed yield is favored, and while it continues fixing $\mathrm{N}_{2}$ for a longer period of time the higher the seed yield will be.

According to the data reported by Vikman and Vessey (1993a) in common bean, and by Salon et al. (2001) in pea, the seed yield (Table 2) of the five evaluated cultivars was a function of the WAI in which the MAR appears (Table 1). Cultivars 'Negro Chapingo' and 'Negro Jamapa' obtained the highest plant dry weight (Table 2), because they started flowering three weeks later than in the others cultivars, and had more time for dry matter accumulation.

In this investigation a high correlation $(\mathrm{r}=0.83, \mathrm{P}<$ $0.01)$ between number of nodules and ARA was observed (Table 3). Therefore, nodule number and weight are reliable indicators of the fixing nitrogen activity. However, caution should be taken because of the existence of nonnitrogen fixing plant-rhizobia symbioses (MartínezRomero, 2003). High correlations $(r=0.85, \mathrm{P}<0.01)$ were also observed between the FW of nodules and the above ground biomass DW, and between the nodules FW and the root DW $(\mathrm{r}=0.87, \mathrm{P}<0.01$; Table 3). Nonetheless, none of the above showed a significant correlation with MAR.

Table 2. Dry weight (DW) of biomass components of five cultivars of common bean (Phaseolus vulgaris L.) inoculated with Rhizobium etli CE-3 grown under greenhouse conditions.

\begin{tabular}{|c|c|c|c|c|c|c|}
\hline \multirow[b]{2}{*}{ Cultivar } & \multirow[b]{2}{*}{$\mathrm{WAS}^{\dagger}$} & \multicolumn{4}{|c|}{ Biomass components of dry weight (g/plant) } & \multirow[b]{2}{*}{ Seeds } \\
\hline & & Stem & Root & Leaf & $\begin{array}{c}\text { Pod } \\
\text { (without seeds) }\end{array}$ & \\
\hline 'Bayomex' & $14.1 \pm 1.0 \mathrm{bc}^{\dagger \dagger}$ & $1.6 \pm 0.4 \mathrm{bc}$ & $1.5 \pm 0.3 \mathrm{~b}$ & $3.3 \pm 0.3 \mathrm{abc}$ & $1.8 \pm 0.3 \mathrm{a}$ & $4.7 \pm 0.6 \mathrm{a}$ \\
\hline 'Canario 107' & $12.9 \pm 0.8 \mathrm{~d}$ & $1.1 \pm 0.2 \mathrm{c}$ & $1.5 \pm 0.7 \mathrm{~b}$ & $2.2 \pm 0.2 \mathrm{c}$ & $2.2 \pm 0.4 \mathrm{a}$ & $5.0 \pm 0.3 \mathrm{a}$ \\
\hline 'Negro Chapingo' & $15.3 \pm 0.7 \mathrm{a}$ & $2.3 \pm 0.2 \mathrm{a}$ & $2.7 \pm 0.4 \mathrm{a}$ & $5.8 \pm 0.4 \mathrm{a}$ & $1.7 \pm 0.5 \mathrm{a}$ & $4.0 \pm 0.3 \mathrm{a}$ \\
\hline 'Negro Jamapa' & $15.3 \pm 0.5 \mathrm{a}$ & $1.8 \pm 0.3 \mathrm{ab}$ & $2.2 \pm 0.6 \mathrm{ab}$ & $5.4 \pm 0.3 \mathrm{a}$ & $2.2 \pm 0.5 \mathrm{a}$ & $5.8 \pm 0.4 \mathrm{a}$ \\
\hline
\end{tabular}


Table 3. Correlations between different characteristics seconded on five cultivars of common bean (Phaseolus vulgaris L.) inoculated with Rhizobium etli CE-3 grown under greenhouse conditions.

\begin{tabular}{|c|c|c|c|c|c|c|c|c|c|c|c|c|}
\hline \multirow[b]{2}{*}{ Plant characteristic } & \multirow[b]{2}{*}{$\begin{array}{l}\text { Root } \\
\text { Length }\end{array}$} & \multirow[b]{2}{*}{$\begin{array}{l}\text { Plant } \\
\text { height }\end{array}$} & \multicolumn{2}{|c|}{ Fresh weight } & \multicolumn{2}{|c|}{ Dry weight } & \multirow[b]{2}{*}{$\begin{array}{l}\text { Nodule } \\
\text { fresh } \\
\text { weight }\end{array}$} & \multirow[b]{2}{*}{$\begin{array}{c}\text { Total } \\
\text { nodules }\end{array}$} & \multirow[b]{2}{*}{$\begin{array}{l}\text { Number } \\
\text { of pods }\end{array}$} & \multirow[b]{2}{*}{$\begin{array}{c}\text { Pod } \\
\text { fresh } \\
\text { weight }\end{array}$} & \multirow[b]{2}{*}{$\begin{array}{l}\text { Pods dry } \\
\text { weight }\end{array}$} & \multirow[b]{2}{*}{$\begin{array}{c}\text { Yield } \\
\text { per plant }\end{array}$} \\
\hline & & & Root & $\mathrm{AGB}^{\dagger}$ & Root & AGB & & & & & & \\
\hline Root fresh weight & $0.58 * * *$ & $0.64 * * *$ & & & & & & & & & & \\
\hline AGB fresh weight & $0.50 * * *$ & $0.64 * * *$ & $0.61 * * *$ & & & & & & & & & \\
\hline Root dry weight & $0.50 * * *$ & $0.60 * * *$ & $0.62 * * *$ & $0.62 * * *$ & & & & & & & & \\
\hline Total nodules & $0.35 * * *$ & $0.40 * * *$ & $0.43 * * *$ & $0.49^{* * *}$ & $0.58^{* * *}$ & $0.48^{* * *}$ & $0.70^{* * *}$ & & & & & \\
\hline Number of pods & 0.04 & 0.11 & -0.03 & 0.20 & 0.30 & 0.36 & -0.09 & 0.13 & & & & \\
\hline Pod fresh weight & 0.28 & -0.03 & 0.08 & 0.32 & 0.20 & 0.26 & -0.10 & 0.08 & 0.32 & & & \\
\hline Pod dry weight & -0.07 & -0.02 & 0.01 & -0.07 & -0.03 & 0.01 & 0.07 & 0.07 & 0.32 & 0.194 & & \\
\hline Yield per plant & -0.12 & -0.01 & -0.06 & -0.09 & -0.20 & -0.09 & 0.08 & -0.02 & 0.20 & 0.245 & $0.64 * * *$ & \\
\hline $\mathrm{ARA}^{\dagger \dagger}$ & -0.11 & -0.01 & 0.15 & 0.25 & -0.09 & -0.09 & $0.63 * * *$ & $0.84 * * *$ & 0.20 & 0.197 & $0.55^{* * *}$ & $0.64 * * *$ \\
\hline
\end{tabular}

${ }^{\dagger}$ Above ground biomass; ${ }^{\dagger \dagger}$ Acetylene reduction assay. ${ }^{* * *} \mathrm{P} \leq 0.0001$

\section{CONCLUSIONS}

The onset of nodule senescence in the symbiotic systems evaluated in this research appears to be independent of the phenological stage (flowering or pod fill) of the host plant using different cultivars. The symbiotic systems that maintain nitrogen fixation during a longer period of time exhibited the highest values of plant dry weight. Finally, from the symbiotic systems evaluated here, it is suggested that number of nodules and the nodule fresh weight can be reliable indicators for estimating nitrogen fixation capacity in the common bean crop.

\section{BIBLIOGRAPHY}

Alesandrini F, R Mathis, G V Sype, D Herouart, A Puppo (2003) Possible roles of a cysteine protease and hydrogen peroxide in soybean nodule development and senescence. New Phytol. 158:131-138.

Andreeva N I, G M Kozharinova, S F Izmailov (1998) Senescence of legume nodules. Russian J. Plant Physiol. 45:101-112.

Balestrasse K B, S M Gallego, M L Tomaro (2004) Cadmium-induced senescence in nodules of soybean (Glycine max L.) plants. Plant and Soil 262:373-381.

Barreiro P M (1997) La producción de frijol en México: diversidad y libre mercado. Claridades Agropec. 47:2-23.

Broughton J W, G Hernández, M Blair, S Beebe, P Gepts, J Vanderleyden (2003) Beans (Phaseolus spp.) - model food legumes. Plant and Soil 252:55-128.

Comba M E, M P Benavides, M L Tomaro (1998) Effect of salt stress on antioxidant defense system in soybean nodules. Austr. J. Plant Physiol. 25:665-671.

Doyle J J (1994) Phylogeny of the legume family: an approach to understanding the origins of nodulation. Annu. Rev. Ecol. Syst. 25:325-349.

Espinosa-Victoria D, C P Vance, P H Graham (2000) Host variation in traits associated with crown nodule senescence in soybean. Crop Sci. 40:103-109.

Evans J P, D Gallesi, C Mathieu, M J Hernández, M Felipe, B Halliwell, A Puppo (1999) Oxidative stress occurs during soybean nodule senescence. Planta 208:73-79.
Fernández-Luqueño F, L Dendooven, A Munive, L Corlay-Chee, L M Serrano-Covarrubias, D Espinosa-Victoria (2008) $\mathrm{Mi}$ cro-morphology of common bean (Phaseolus vulgaris L.) nodules undergoing senescence. Acta Physiol. Plant. 30:545552.

Fisher M C T, D M Eissenstat, J P Lynch (2002) Lack of evidence for programmed root senescence in common bean (Phaseolus vulgaris) grown at different levels of phosphorus supply. New Phytol. 153:63-71.

Gogorcena Y, I Iturbe-Ormaetxe, PR Escuredo, M Becana (1995) Antioxidant defenses against activated oxygen in pea nodules subjected to water stress. Plant Physiol. 108:753-759.

Gogorcena Y, J A Gordon, P R Escuredo, R F Minchin, J F Witty, J F Moran, M Becana (1997) $\mathrm{N}_{2}$ fixation, carbon metabolism, and oxidative damage in nodules of dark-stressed common bean plants. Plant Physiol. 113:1193-1201.

González E J, M M Marketon (2003) Quorum sensing in nitrogenfixing rhizobia. Microbiol. Mol. Biol. Rev. 67:574-592.

Graham P H (1963) Antibiotic sensitivities of the nodule bacteria. Austr. J. Biol. Sci. 16:557-560.

Hardarson G, S K A Danso (1993) Methods for measuring biological nitrogen fixation in grain legumes. Plant and Soil 152:19-23.

Howard T, H J Ougham, C Wagstaff, A D Stead (2003) Defining senescence and death. J. Exp. Bot. 54:1127-1132.

Lawn R J, W A Brun (1974) Symbiotic nitrogen fixation in soybean. III. Effect of supplemental nitrogen and intervarietal grafting. Crop Sci. 14:22-25

Limpens E, T Bisseling (2003) Signaling in symbiosis. Curr. Opin. Plant Biol. 6:343-350.

Martínez-Romero E (2003) Diversity of Rhizobium-Phaseolus vulgaris symbiosis: overview and perspectives. Plant and Soil 252:1123.

Matamoros M A, L M Baird, P R Escuredo, D A Dalton, $\mathbf{F} \mathbf{R}$ Minchin, I Iturbe-Ormaetxe, M C Rubio, J F Moran, A J Gordon, M Becana (1999) Stress-induced legume root nodule senescence. Physiological, biochemical, and structural alterations. Plant Physiol. 121:97-111.

McDermott T R, P H Graham (1989) Bradyrhizobium japonicum inoculant mobility, nodule occupancy, and acetylene reduction in the soybean root system. Appl. Env. Microbiol. 55:24932498.

Muller J, T Boller, A Wiemken (2001) Trehalose becomes the most abundant non-structural carbohydrate during senescence of soybean nodules. J. Exp. Bot. 52:943-947.

Nosengo N (2003) Fertilized to death. Nature 425:894-895. 
Pfeiffer N E, C M Torres, F W Wagner (1983) Proteolytic activity in soybean root nodules. Activity in host cell citosol and bacteroids throughout physiological development and senescence. Plant Physiol. 71:797-802.

Pladys D, J Rigaud (1988) Lysis of bacteroids in vitro and during the senescence in Phaseolus vulgaris nodules. Plant Physiol. Biochem. 26:179-186.

Puppo A, K Groten, F Bastian, R Carzaniga, M Soussi, M M Lucas, M R Felipe, J Harrison, H Vanacker, C F Foyer (2005) Legume nodule senescence: roles for redox and hormone signaling in the orchestration of the natural aging process. New Phytol. 165:683-701.

Roger K (1982) Free-living dinitrogen-fixing bacteria. In: Methods of soil analysis. Part. 2. Chemical and Microbiological properties. A L Page, R H Miller, D R Keeney (eds) 2nd. ed. American Society of Agronomy and Soil Science Society of America. Madison, Wisconsin USA. pp:1071-1076.

Salon C, N G Munier-Jolainn, G Duc, V Anne-Sophie, D Grandgirard, A Larmure, R J N Emery, B Ney (2001) Grain legume seed filling in relation to nitrogen acquisition: A review and prospects with particular reference to pea. Agronomie 21:539-552.

SAS Institute (1989) Statistic guide for personal computers. Version 6.04. SAS Institute, Cary. 429 p.

Schultze M, A Kondorosi (1998) Regulation of symbiotic root nodule development. Annu. Rev. Gen. 32:33-57.

Staehelin C, J Muller, R B Mellor, A Wiemken, T Boller (1992) Chitinase and peroxidase in effective $\left(\mathrm{fix}^{+}\right)$and ineffective (fix) soybean nodules. Planta 187:295-300.
Swaraj K, J S Laura, N R Bishnoi (1994) Dark treatment effects on nitrogen fixation and enzymes associated with scavenging hydrogen peroxide in clusterbean nodules. Plant Physiol. Biochem. 32:115-119.

Swaraj K, S Dhandi, S Sheokand (1995) Relationship between defense mechanism against activated oxygen species and nodule functioning with progress in plant and nodule development in $\mathrm{Ca}$ janus cajan L., Millsp. Plant Sci. 112:65-74.

Swaraj K, N R Bishnoi (1996) Phisiological and biochemical basis of nodule senescence in legumes: a review. Plant Physiol. Biochem. 23:105-116.

Timmers A C J, E Soupene, M C Auriac, F Billy, J Vasse, P Boistard, G Truchet (2000) Saprophytic intracellular rhizobia in alfalfa nodules. Mol. Plant Microbe In. 13:1204-1213.

Trinchant J C, A Boscari, G Spennato, G V Sype, D L Rudulier (2004) Proline betaine accumulation and metabolism in alfalfa plants under sodium chloride stress. Exploring its compartmentalization in nodules. Plant Physiol. 135:1583-1594.

Vikman P, J K Vessey (1992) The decline in $\mathrm{N}_{2}$ fixation rate in common bean with the onset of pod filling: Fact or artifact. Plant and Soil 147:95-105.

Vikman P, J K Vessey (1993a) Ontogenetic changes in root nodule subpopulations of common bean (Phaseolus vulgaris L.). I. Nitrogenase activity and respiration during pod-filling. J. Exp. Bot. 44:563-569.

Vikman P, J K Vessey (1993b) Ontogenetic changes in root nodule subpopulations of common bean (Phaseolus vulgaris L.). II. Protein content and carbohydrate pools. J. Exp. Bot. 44:571577. 